\title{
The Corporate Governance Code and Compliance by Maltese Listed Companies
}

\author{
Submitted 21/12/18, $1^{\text {st }}$ revision $13 / 1 / 19,2^{\text {nd }}$ revision 20/2/19 accepted 26/3/19
}

\author{
Peter J Baldacchino ${ }^{1}$, Claire Vella ${ }^{2}$, Simon Grima ${ }^{3}$
}

\begin{abstract}
:
Purpose: In this paper we lay out the evaluation of non-compliance with the Code of Principles of Good Corporate Governance and the analyses of the adequacy of the explanations provided thereof, including the overall effectiveness of the existing regulatory framework.

Design/methodology/approach: To achieve the objectives of this study, a review of the noncompliance section of the corporate governance statements of each Maltese listed company was carried out for the years 2012, 2014 and 2016. Furthermore, 13 semi-structured interviews were held.

Findings: The paper finds that a general insufficiency in the explanations provided for noncompliance exists. Some entities give only lip service to the provisions of the Code as they fail to realise the benefits an entity may reap from having good corporate governance structures in place. There is a lack of education and awareness in this regard, and not only on the part of companies but also on the part of shareholders who seem to make minimal use of the information provided in the corporate governance statements.

Practical implications: The study raises awareness of the need of improving corporate governance practices, as well as education on corporate governance, across Maltese listed companies. It is hoped that the recommendations made may encourage entities to improve in their reporting and the regulator to provide further guidance to entities to do so.

Originality/value: Prior to the amendment of existing rules, increased enforcement of the current regulatory framework and monitoring by the regulator is required. The study highlights the misconceptions on the auditor's role in corporate governance.
\end{abstract}

Keywords: Non-Compliance, explanations, Corporate Governance, Maltese listed companies.

JEL code: $G 34$.

Paper type: Research article.

\footnotetext{
${ }^{1}$ University of Malta, Head Department of Accountancy, Faculty of Economics, Management and Accountancy, corresponding author, peter.j.baldacchino@um.edu.mt

${ }^{2}$ University of Malta, Graduate Accountant, Department of Accountancy, Faculty of Economics, Management and Accountancy, claire.vella.95@gmail.com

${ }^{3}$ University of Malta, Head, Department of Insurance, Faculty of Economics, Management and Accountancy, corresponding author, simon.grima@um.edu.mt
} 


\section{Introduction}

Despite the overhaul in corporate governance ('CG') regulation and increased awareness of the importance of CG in the modern economic environment, noncompliance with CG codes is inadequately explained, and is an issue, which has shown to be persistent. As a result, several academics have arrived at the same conclusion as Giannakopoulou et al. (2016), Arcot, Bruno and Faure-Grimaud (2010) that companies simply abide by the requirements for the sake of being compliant, providing explanations which are "totally uninformative" (p.200). Thus, these companies "comply with the 'letter' of the law, but not with the 'spirit"'(p. 200), (Suryanto and Grima, 2018).

This issue has also been highlighted in Malta where Azzopardi (2012) identified that one of the predominant weaknesses of corporate governance in Malta is "a general insufficiency in the reasons disclosed for non-adherence to the Code" (p.134). In fact, the inadequacy of explanations provided for deviations from the Code by Maltese listed companies ('MLCs') is the main issue which discourages users from relying on the information presented in the corporate governance statement ('CGS'). Therefore, there is a lack of transparency, and it appears that the quality of explanations has not improved over the last few years (Debono, 2016).

Although several studies on CG have been carried out in Malta, none specifically address the issue of non-compliance, and the explanations provided thereof. Thus, the main objective in this paper is for us, to present an analyses of the degree of noncompliance and why this non-compliance exists, as well as to give an explanations on how this issue can be improved. In doing so, we also carry out an analysis of the existing regulatory framework, including an evaluation of the roles of the regulatory authority ('RA') and auditors in overseeing and reviewing CG in MLCs.

\section{Literature Review}

\subsection{The Code of Principles of Good Corporate Governance}

Malta first adopted a corporate governance code in 2001. The development of corporate governance in Malta, along with the initial drafting of The Code of Principles of Good Corporate Governance ('the Code'), was profoundly influenced by its development in the UK and the OECD Principles of CG (Bezzina et al., 2014). The Code applies to companies, which are listed on a regulated market. Such companies are expected to draw up a CGS in the annual report (MFSA, 2011).

The Code, last revised in 2011, consists of twelve main principles. Adherence to the principles of the Code increases transparency, disclosure and shareholder protection. The Code adopts a comply-or-explain ('CoE') approach, whereby companies either comply with the principles or provide reasons for non-compliance (MFSA, 2011). 


\subsection{The Comply-or-Explain Principle}

The intention of CG codes adopting a CoE approach is not for companies to comply with all the principles therein, but rather, when provisions are not suitable for certain organisations, then they are not expected to comply (Seidl et al., 2009). Thus, the $\mathrm{CoE}$ principle grants flexibility as it acknowledges the fact that a 'one-size-fits-all' approach to CG is inappropriate, as no single company is the same as another (MacNeil and Li, 2006). Nonetheless, in the event of deviations, companies must give an adequate explanation for non-compliance (Seidl et al., 2009).

Inadequate explanations for non-compliance undermine the whole point of the $\mathrm{CoE}$ principle (Seidl et al., 2013) because its core lies in the company's obligation to disclose reasons for non-compliance (MacNeil and $\mathrm{Li}, 2006$ ). As a result, when the $\mathrm{CoE}$ principle is used superficially, transparency is considerably diluted (Sergakis, 2015). After all, it is where adequate and meaningful explanations are provided, that the flexibility of the CoE principle is beneficial. Otherwise, the 'explain' part of CG codes will have no relative significance (Arcot et al., 2010).

\subsection{The Roles of Auditors and the Regulatory Authority}

\section{(i) THE ROLE OF AUDITORS}

The effective application of the $\mathrm{CoE}$ principle also requires the involvement of auditors, for the purpose of disclosing the adequacy of reporting on CG (Horak and Bodiroga-Vukobrat, 2011). In Malta, Listing Rule 5.98 requires the external auditor of the company to draw up a report, which confirms that the CGS has been prepared in line with the Code and that it includes the disclosures required by the Listing Rules. This report is part of the annual report, and it is distinct from the opinion on the financial statements. However, the auditor is not obliged to give any assurance on the CG function within the entity (Listing Authority, 2018).

Although it may be argued that the auditor's role is vital as verification could enhance the quality of CGSs (Shrives and Brennan, 2015), as things stand, the auditor only confirms that the CGS has been prepared in line with the Code. In fact, Cauchi's findings show that only $50 \%$ of investors believe that the auditor's review increases their level of confidence in the CGS (Cauchi, 2009). It seems that auditors participate in "standard ritualistic behaviour" (Shrives and Brennan, 2015, p.91), not only because they use similar wording and structures of the report, but they also fail to raise any particular concerns on issues relating to non-compliance or the quality of explanations (Shrives and Brennan, 2015).

\section{(ii)THE ROLE OF THE REGULATORY AUTHORITY}

Regulatory frameworks adopting the $\mathrm{CoE}$ approach generally empower shareholders to evaluate and respond to non-compliance themselves, always assuming that an efficient market is in place (Keay, 2014). However, in practice, involvement on the part of shareholders is minimal as no such monitoring of CG practices is taking 
place (Horak and Bodiroga-Vukobrat, 2011). In fact, this is the current situation in Malta, as shareholders merely focus "on the dividends and share prices" (Schembri, 2016, p.101). Therefore, oversight of compliance with the recommendations of CG codes and action in the event of misleading disclosures is required by RAs to improve the exercise of the CoE principle (Horak and Bodiroga-Vukobrat, 2011). Through their involvement, regulators will enable better communication, exchange of views and interaction between users of the CoE principle (Sergakis, 2015).

Despite the possible advantages of regulatory oversight and sanctions, some argued that it may lead to undermining the shareholder's role in CG and the voluntary nature of CG codes (Davies et al., 2011; Financial Reporting Council, 2011). Furthermore, if a regulator is appointed, this could not only result in additional costs but could also lead to an 'us vs them' scenario (Keay, 2014). Thus, for regulatory oversight to be beneficial to CG, the regulatory body must encourage the comprehensive and reliable disclosure of information, while ensuring that the quality of the information provided is preserved (Keay, 2014).

A number of Maltese studies (Azzopardi, 2012; Debono, 2016; Gatt, 2017; Schembri, 2016) have also pointed towards the involvement of RAs in ensuring adequate explanations for non-compliance with the Code. These explanations have shown to be insufficient and as a result, require users to find other means to determine the reasons for such non-compliance. It seems that it is not stricter regulations that are necessary, but rather more supervision on the existing rules (Debono, 2016).

\subsection{Non-Compliance to the Corporate Governance Code}

Several academics have looked into the aspect of non-compliance with national CG codes. A recurring issue that has come to light is the fact that non-compliance is not sufficiently explained, and in some cases, no explanation is provided at all (Akkermans et al., 2007; Arcot et al., 2010). Explanations provided for noncompliance, fail to adequately explain the reasons for such deviations and very often, companies, which fail to comply usually, provide similar insufficient explanations (Arcot et al., 2010). These findings have led to the repeated conclusion of compliance, which is in actual fact "symbolic" (Akkermans et al., 2007, p.1106), as companies adhere to CG codes for the sake of being compliant, and thus circumvent the real intention of such codes (Arcot et al., 2010). As a result, CG is viewed as a "box-checking exercise" (Bozec and Dia, 2012, p.243), rather than essential practice embedded in an organisation's culture.

Malta is no exception to this. In fact, one of the main weaknesses concerning CG in MLCs is the overall inadequacy of the explanations provided in terms of noncompliance with the Code (Azzopardi, 2012). Schembri's findings (2016) also highlighted the fact that MLCs provide inadequate justifications for deviations from the principles of the Code. In fact, he added that it is as if listed entities expect 
stakeholders to rely on their good faith, without providing any suitable explanation for non-compliance. Furthermore, Baldacchino et al. (2015 and 2017) concluded that the only reason why MLCs are complying with the Code is that they are obliged to do so by the Listing Rules, while Baldacchino et al. (2018) held that companies only adhere superficially with the Code. All these factors point towards a symbolic form of compliance. These findings are therefore comparable to the aforementioned studies.

Thus, there is a recurring need for the improvement of explanations for noncompliance, whereby companies have to provide more meaningful justifications to stakeholders. In fact, the $\mathrm{EC}^{4}$ highlighted the need for the enhancement of the quality of explanations for non-compliance since the majority are unsatisfactory, and there is inadequate regulatory oversight in most Member States (European Commission, 2011). The EC also issued a Recommendation on this issue in 2014 wherein Section III paragraph 8 it outlined that in cases of non-compliance, companies should:

- explain in what manner the company has departed from a recommendation;

- describe the reasons for the departure;

- describe how the decision to depart from the recommendation was taken within the company;

- where the departure is limited in time, explain when the company envisages complying with a particular recommendation;

- where applicable, describe the measure taken instead of compliance and explain how that measure achieves the underlying objective of the specific recommendation or of the code as a whole, or clarify how it contributes to good corporate governance of the company (European Commission, 2014, p.4)

By providing such information, companies will give shareholders and other stakeholders the opportunity to adequately assess the implications of noncompliance with the principles of CG codes (European Commission, 2014).

\section{Research Methodology}

To collect the primary data we used two sources. The first source included an analysis of the annual reports of listed companies as may be seen in Table A1 in Appendix 1. The non-compliance section of the CGSs of equity companies listed on the MSE was analysed in detail and compared to the Code for the years 2012, 2014 and 2016. As at $31^{\text {st }}$ March 2018, twenty-three companies had an equity listing on the MSE and in total, fifty-six ${ }^{5}$ CGSs were analysed. In reviewing these statements,

\footnotetext{
${ }^{4}$ European Commission's Green Paper - The EU corporate governance framework.

${ }^{5}$ Vide Appendix 3.1 for list of Corporate Governance Statements Analysed.
} 
the focus was placed on the explanations provided by MLCs to determine or otherwise their adequacy in terms of the requirements, and the spirit of the Code.

In the $2^{\text {nd }}$ instance, semi-structured interviews were also carried out. These were mainly targeted towards the company secretaries of the MLCs, since in the majority of cases, if not all, it is the latter who prepare the CGS of the company. Furthermore, since the roles of auditors and the RA was also evaluated in terms of the Maltese regulatory framework, interviews were also held with members of audit firms as well as a representative of the MFSA. In total, thirteen interviews were carried out, whereby nine were held with members of MLCs, three with audit firm representatives and one with a representative of the MFSA. Interview questions were adapted according to the interviewee.

\section{Findings and Discussion}

\subsection{The Maltese Regulatory Framework}

This study found that the Code allows for the setup of appropriate CG structures in MLCs (13/13). As highlighted by two interviewees (2/13), it seems that the issues that arise in CG are not as a result of the Code itself but rather due to its implementation. It is where entities comply with the letter but not with the spirit of the Code that the existing framework loses its effectiveness. As a result, this issue sparks debate on whether the Code should be made mandatory. This study found great resistance to the latter (12/13), with many participants expressing that this would result in a one-size-fits-all set of rules leading to no other than a box-ticking exercise. Indeed, this study found that the existing CG framework, that is a code based on the $\mathrm{CoE}$ principle, is an effective approach to $\mathrm{CG}$ as it grants flexibility. However, it was also highlighted that for the existing framework to be effective, it requires adequate and meaningful explanations for non-compliance.

This is understandable, given that good governance is not simply determined by the structures or procedures an entity has in place, but by its commitment to adopt these principles in its day-to-day activities. Thus, what is required is more awareness on the importance of CG so that companies can understand the real implications behind having good $\mathrm{CG}$ systems in place, and the benefits an organisation may reap by implementing these structures. This coupled with increased regulatory involvement may be a better alternative to the mandatory imposition of all principles.

\subsection{The Roles of Auditors and the Regulatory Authority}

\section{(i) THE ROLE OF AUDITORS}

This study found that the auditor's role in CG is rather relevant since ultimately the information in the CGS is being corroborated. Indeed, research participants agreed that the auditor's report on CG increases shareholders' confidence on the CGS ( $\overline{\mathrm{x}}=$ 4.00). However, this study also highlighted the misconceptions on the auditor's role 
on the part of MLCs since most disagreed that in practice auditors do not really provide assurance on the CG function $(\bar{x}=2.92)$. Thus, while the auditor is not obliged to give any assurance on the $\mathrm{CG}$ function, it seems that there exist an expectations gap of what auditors are actually confirming in their report on CG. In fact, MLC representatives (5/9) themselves emphasised that auditors give a lot of significance to the CGS and that what it includes reflects reality. On the other hand, Debono (2016) held that financial analysts and major shareholders believed that "auditors barely do anything to ascertain [the CGS'] reliability" (Debono, 2016, p.71). Therefore, this indicates that the auditor's real efforts are unknown to external parties. Thus, the misconceptions on the auditor's role go both ways. While MLCs attribute the auditor's involvement to providing assurance due to their thorough review of the CGS and CG practices thereof, their work may be hidden to other stakeholders.

\section{(ii) THE ROLE OF THE REGULATORY AUTHORITY}

This study highlights that while the MFSA has the authority to initiate various regulatory actions against MLCs for non-compliance since compliance is a requirement of the Listing Rules, no such action has ever been instituted. Compliance procedures on the CGS have never been carried out by the authority owing to other supervisory priorities. However, there are plans for this work to be carried out in the near future. As is the norm, the authority will try to adopt a fair process, whereby communication is exchanged before taking corrective action in the form of fines, penalties or requesting company announcements.

Nevertheless, views on increased regulatory involvement amongst different interviewees were contrasting. While both the MFSA and audit firm representatives (4/4) agreed that more involvement is required on the part of the regulator, unsurprisingly, in the case of MLC interviewees most (7/9) did not agree there should be more involvement by the regulator since the regulator is already involved in many other issues, and according to one of them $(1 / 7)$, there needs to be a limit to regulatory involvement as it can result in an "overkill of regulation".

Regulatory involvement will undoubtedly result in several advantages and, given the current situation, such involvement is essential. However, there may be a fine line with the authority going overboard. As indicated by Keay (2014), the important thing is that the regulator is not simply considered as a watchdog imposing fines or penalties, but one who also provides a supporting role. The authority needs to strive to build a relationship based on communication, making itself more accessible to MLCs to ask for guidance if necessary. At the same time, it needs to keep its stand as regulator and take the necessary and proper corrective action where required in a timely and consistent manner. 


\subsection{Non-Compliance to the Corporate Governance Code}

\section{(I) PREPARATION OF THE CORPORATE GOVERNANCE STATEMENT}

The review of the annual reports of MLCs highlighted a number of differences in reporting of the CGSs across different entities. The main issues were in terms of the format of the CGS. For instance, in the case of one particular MLC, while the Code outlines that the CGS is to be divided into two main sections, with the first section dealing with compliance to the principles and the second section dealing with noncompliance, no such distinction was made in the CGSs analysed.

Although entities have a responsibility to provide adequate disclosure, one may also question whether the Code provides enough guidance to MLCs in the preparation of their CGS. The Code itself simply requires the CGS to include one section dealing with compliance with the Code and another section dealing with non-compliance, including descriptions providing shareholders with "a clear and comprehensive picture of a company's governance arrangements" (MFSA, 2011, p.1). Similarly, in terms of the explanations, the Code requires "a careful and clear explanation which shareholders should evaluate on its merits" (MFSA, 2011, p.1). Considering that this is a fairly recent requirement and that no regulatory monitoring has taken place so far, one must appreciate that MLCs have been going through a continuous learning process.

The MFSA representative held that the Code was even vaguer prior to the 2011 amendments, yet s/he also pointed out that there is still room for improvement. This could possibly be in the form of further guidance in the preparation of the CGS on the MFSA's part. In fact, this was also suggested by one of the interviewees (1/13). However, entities currently resort to their auditors or each other for mutual support. Indeed, a number of company secretary interviewees (3/7) also mentioned that they form part of a forum giving the opportunity to communicate and exchange regulatory ideas, including those on $\mathrm{CG}$.

\section{(II) ADHERENCE TO THE CODE}

The explanations provided in the non-compliance section of the CGSs by MLCs were analysed to identify the main areas of non-compliance with the Code. Table 1 Identifies the main areas of non-compliance as reported by MLCs in the noncompliance section of their CGS. The main non-compliance areas are ranked in order of decreasing instances of non-compliance.

Table 1. Code Areas Breached by MLCs

\begin{tabular}{|l|l|l|l|l|l|}
\hline Code Area & $\mathbf{2 0 1 2}$ & $\mathbf{2 0 1 4}$ & $\mathbf{2 0 1 6}$ & Total \\
\hline Provision 9.3 & $\begin{array}{l}\text { Mechanism to resolve conflicts between } \\
\text { minority and controlling shareholders. }\end{array}$ & 13 & 14 & 16 & $\mathbf{4 3}$ \\
\hline $\begin{array}{l}\text { Provision } \\
\mathbf{4 . 2 . 7}\end{array}$ & Succession Policy for the BOD. & 12 & 12 & 15 & $\mathbf{3 9}$ \\
\hline Principle 8B & Nomination Committee. & 14 & 12 & 12 & $\mathbf{3 8}$ \\
\hline
\end{tabular}




\begin{tabular}{|c|c|c|c|c|c|}
\hline Principle 3 & $\begin{array}{l}\text { BOD should be composed of executive } \\
\text { and non-executive directors. }\end{array}$ & 5 & 6 & 7 & 18 \\
\hline Principle 7 & Evaluation of the Board's Performance. & 3 & 5 & 5 & 13 \\
\hline Provision 7.1 & $\begin{array}{l}\text { Appointing a Committee to carry out the } \\
\text { performance evaluation. }\end{array}$ & 4 & 4 & 4 & 12 \\
\hline Provision 2.3 & A chairman should be independent. & 3 & 3 & 3 & 9 \\
\hline $\begin{array}{l}\text { Provision } \\
\text { 8.A.1 }\end{array}$ & $\begin{array}{l}\text { Remuneration Committee should be } \\
\text { chaired by an independent non-executive } \\
\text { director. }\end{array}$ & 2 & 3 & 3 & 8 \\
\hline Principle 2 & Chairman and Chief Executive. & 3 & 2 & 1 & 6 \\
\hline Provision 2.1 & $\begin{array}{l}\text { Division of responsibilities between } \\
\text { Chairman and Chief Executive should be } \\
\text { set out in writing. }\end{array}$ & 2 & 2 & 2 & 6 \\
\hline Principle 6 & Succession plan for senior management. & 2 & 1 & 3 & 6 \\
\hline Provision 9.4 & $\begin{array}{l}\text { Minority shareholders should be allowed } \\
\text { to present issues to the BOD. }\end{array}$ & 1 & 1 & 4 & 6 \\
\hline Principle 8A & Remuneration Committee. & 1 & 1 & 3 & 5 \\
\hline Provision 4.3 & $\begin{array}{l}\text { The BOD should organise regular } \\
\text { information Sessions. }\end{array}$ & 2 & 2 & 1 & 5 \\
\hline Provision 3.1 & $\begin{array}{l}\text { BOD should appoint one of the } \\
\text { independent non-executive directors to be } \\
\text { a senior independent director. }\end{array}$ & 1 & 1 & 1 & 3 \\
\hline $\begin{array}{l}\text { Provision } \\
\text { 6.4.1 }\end{array}$ & $\begin{array}{l}\begin{array}{l}\text { Provision of professional training } \\
\text { sessions. }\end{array} \\
\end{array}$ & 1 & 1 & 1 & 3 \\
\hline $\begin{array}{l}\text { Provision } \\
\text { 4.2.3 }\end{array}$ & $\begin{array}{l}\text { A member of the audit committee shall be } \\
\text { independent. }\end{array}$ & 1 & 1 & 0 & 2 \\
\hline Provision 5.2 & $\begin{array}{l}\text { Attendance of board members should be } \\
\text { reported to shareholders at annual general } \\
\text { meetings. }\end{array}$ & 1 & 1 & 0 & 2 \\
\hline Other & Various areas & 1 & 3 & 6 & 10 \\
\hline Total & & 72 & 75 & 87 & 234 \\
\hline
\end{tabular}

As identified from the table, most instances of non-compliance related to Provision 9.3, which requires entities to establish procedures to resolve conflicts between minority and controlling shareholders. Provision 4.2.7 which requires an entity to develop a succession policy for the Board of Directors ('BOD') also showed a high level of non-compliance, as well as Principle 8B which requires MLCs to set up a Nomination Committee. Furthermore, there were no instances of non-compliance reported in terms of Principles 10,11 and 12. These findings are similar to what was found by Baldacchino et al. (2015) who identified that instances of non-compliance "mainly related to shareholder conflicts, the absence of the Nominations Committee and the lack of board performance evaluation" (Baldacchino et al., 2015, p.15).

The persistent non-compliance in these areas may be indicative of their limited applicability in MLCs, especially in companies, which are smaller in size. In fact, this study found that the main reasons for non-compliance amongst MLC 
interviewees (7/9) were due to practical problems where the principles or provisions of the Code are inapplicable to the entity. This is why entities need to be given an opportunity to explain where they are not compliant as otherwise, structures will be put in place only to "rubber stamp" what the Code requires. After all, it is the intention of the Code to allow flexibility, where as long as adequate explanations for non-compliance are provided to users, non-compliance is acceptable.

Therefore, the question is not whether or not the level of compliance with the Code is satisfactory, as the Code itself permits non-compliance. Rather, the question is whether, through their explanations, MLCs give comfort to shareholders that despite those instances of non-compliance, the entity has adopted a system of good governance. Yet in a number of MLCs, this is evidently not the case.

\section{(III) EXPLANATIONS FOR NON-COMPLIANCE}

As stated earlier ${ }^{6}$, in its recommendations the EC identified five components to be included in an explanation for non-compliance. To obtain a better understanding of what interviewees would consider being a useful explanation, respondents were asked to rate their agreement to these five components, as demonstrated in Figure 1.

\section{Figure 1. Statements related to Explanations for Non-Compliance}

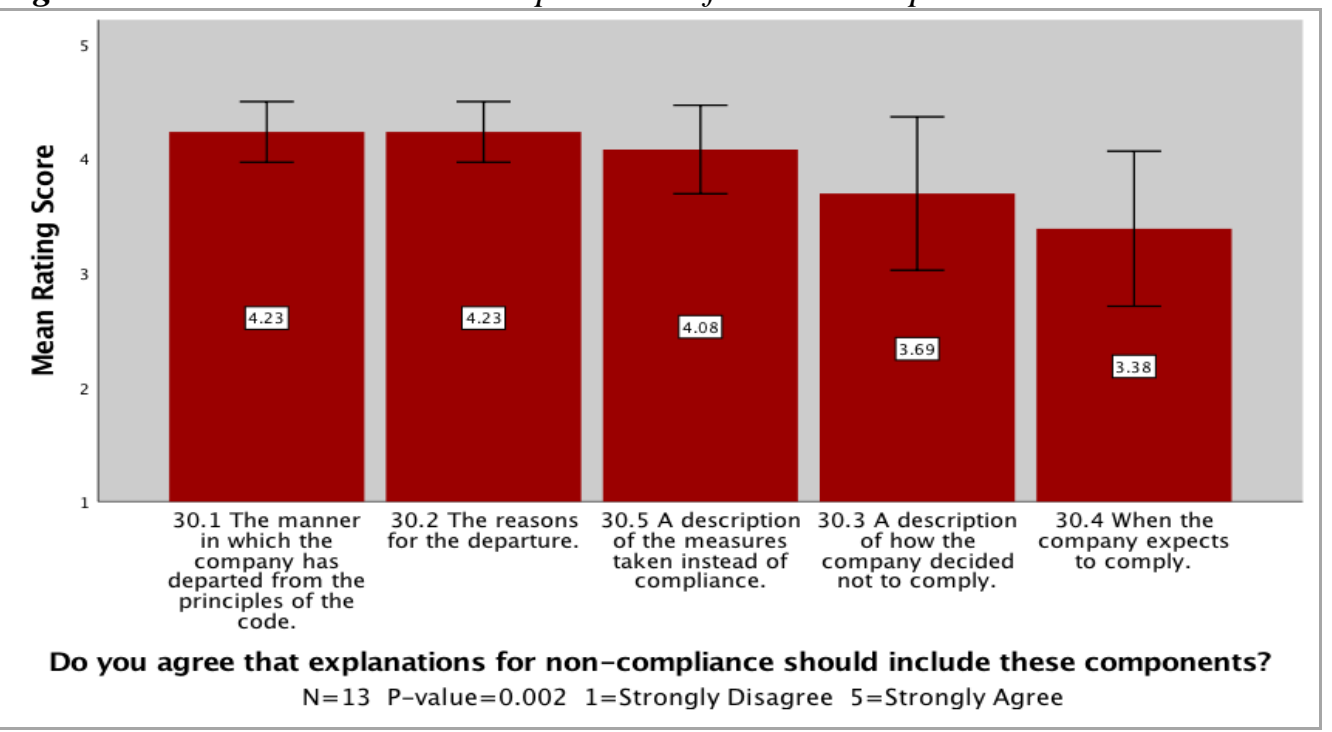

This results of the study revealed that of these five components, the most important aspects of an explanation for non-compliance are the manner in which the company has departed from the Code $(\bar{x}=4.23)$ and the reasons for that departure $(\bar{x}=4.23)$, together with a description of the measures taken instead of compliance $(\bar{x}=4.08)$,

\footnotetext{
${ }^{6}$ Vide Section 2.4.
} 
where applicable. However, the other two components were not seen to be as significant.

Nonetheless, the analysis of the annual reports revealed several issues concerning the explanations, particularly that while in general, almost all companies identify the manner in which they departed from the principles or provisions of the Code, a few companies simply state that they are not compliant, without providing any explanation thereof. Some examples are presented in Table 2.

Table 2. Why are the Reasons for Non-Compliance being Omitted?

\section{Bank of Valletta plc 2016 - Principle 7:}

"During the year under review, the Board did not undertake an evaluation of its own performance, the Chairman's performance and that of its committees." (p.33)

Lombard Bank Malta plc 2016 - Provision 9.3:

"There are no procedures disclosed in the Bank's Memorandum or Articles as recommended in Code Provision 9.3 to resolve conflicts between minority shareholders and controlling shareholders." (p.19)

Plaza Centres plc 2016 - Provision 9.4:

"Plaza does not have a policy in place to allow minority shareholders to present an issue to the Board." (p.16)

Similarly, there are instances whereby an entity provides reasons for non-compliance where companies explain that the BOD "believes" or "feels" that something is appropriate, but they do not outline the reasoning behind such conclusions. Similarly, in other cases, entities justify non-compliance by stating that the BOD did not consider it "necessary" to be carried out. Table 3 provides examples of this.

Table 3. How Valid is the Stated Justification for Non-Compliance?

\section{Plaza Centres plc 2016 - Provision 2.1:}

"Although the posts of the Chairman and the Chief Executive Officer are occupied by different individuals in line with Code Provision 2.1, the division of their responsibilities has not been set out in writing. Nevertheless, the Board feels that there are significant experience and practice that determines the two roles." (p.16)

MIDI plc 2016 - Principle 7:

"In the context of the nature of the Company's operations and the stage of its operations together with the composition and roles of the Board, the Board did not consider that such a formal evaluation of performance was necessary, nonetheless a review of the strengths and weaknesses of each director is taken into consideration when reviewing the composition of the Board's committees." (p.21)

Perhaps the agency theory could help in explaining the reason why although the MLCs are aware that the reason for the departure from the Code is an essential requirement, some still fail to provide this fundamental piece of information. MLCs are providing explanations that will satisfy their own needs while portraying to shareholders that they adhere to CG regulation. In this respect, Bozec and Dia (2012), Grima et. al., (2017) maintain that companies do seek to adhere symbolically 
to the code to portray a reputable image, with the objective to reduce the costs consequent to non-compliance and/or monitoring by RAs.

Furthermore, the study results revealed that in the case of breaches from the Code which remain the same from year to year, MLCs tend to use the same explanation or very similar explanations. In most cases, it is only when there are changes, particularly if in one year the entity is non-compliant with a principle, but in the following year it is or vice-versa, that the explanations provided are different. Examples of this are provided in Table 4.

Table 4. Should there be CG Improvement Over Time?

RS2 Software plc 2012, 2014 \& 2016 - Principle 2:

"Code Provision 2.3 states that the Chairman should be independent. Mr Mario Schembri, who currently holds the position of Chairman, cannot be deemed independent due to his involvement held in the Company." (2016, p.38)

International Hotel Investments plc 2012, 2014 \& 2016 - Principle 7:

"Under the present circumstances, the board does not consider it necessary to appoint a committee to carry out a performance evaluation of its role, as the board's performance is always under the scrutiny of the shareholders." (2016, p.13)

Similarities are also evident in the explanations of different firms. In some cases, the explanations used are practically the same, except for a few minor changes in wording. This could be indicative that the same author is behind the wording. Table 5 presents examples of similar explanations across different MLCs.

Table 5. Why are CGSs so alike despite being Unstructured? Grand Harbour Marina plc \& Medserv plc 2016 - Provision 9.3:

A. Grand Harbour Marina plc: "The Company does not have a formal mechanism in place as required by Code provision 9.3 to resolve conflicts between minority shareholders and controlling shareholders and no such conflicts have arisen." (p.20)

B. Medserv plc: "The Company does not have a formal mechanism in place as required by Code provision 9.3 to resolve conflicts between minority shareholders and controlling shareholders and no such conflicts have arisen." (p.22)

Tigne Mall plc \& MIDI plc 2016 - Provision 4.2.7:

A. Tigne Mall Plc: "The Board notes that pursuant to the Company's Memorandum and Articles of Association, the appointment of Directors to serve on the Board of Directors is a matter which is entirely reserved to the shareholders of the Company. Thus, the Board does not consider it practical to develop a succession policy for the future composition of the Board. However, as indicated in the statement of compliance, all newly appointed Directors are given an adequate induction course in the operations, activities and procedures of the Company to be able to carry out the function of a Director in an effective manner. The Board also notes the emphasis in this Code provision on the executive component of the Board and points out that the Company's Board is composed entirely of non-executive members." (p.14)

B. MIDI plc: "The Board notes that pursuant to the Company's Memorandum and Articles of Association of the Company, the appointment of directors to serve on the 
Board of Directors is a matter which is entirely reserved to the shareholders of the Company, who are afforded the power to nominate and elect a new board of directors on an annual basis. Thus, the Board does not consider it practical to develop a succession policy for the future composition of the Board. However, as indicated in the statement of compliance, all newly appointed directors are given a thorough induction course in the operations, activities and procedures of the Company by Senior Management to be able to carry out the function of a Director in an effective manner." (p.21)

Using boilerplate language makes the CGS lose its importance, as rather than reflecting the entity's situation, it becomes another generic statement, which is prepared only for the sake of apparently abiding by the regulations. As indicated by Hooghiemstra and van Ees (2011), this type of behaviour results in a one-size-fits-all approach, leaving no significant influence on users.

Therefore, one may ask whether this form of tackling the Code is of any benefit to the stakeholders, including the entity itself. This type of behaviour may also be indicative of MLCs' failure to realise that having a system of good governance in place has its advantages, affecting all aspects of the organisation. Until such realisation takes effect, there will be much a reluctance to prepare a CGS tailored to the organisation.

Inadequate explanations for non-compliance mirror MLCs failure to observe the real intention of the Code, while confirming that some entities comply with the Code only because it is required by law. The indications are that $\mathrm{CG}$ is seldom given the importance, which it merits. Of course, box-ticking from year to year without improvement leads to nowhere. The impetus has to be there for implementing a real governance system across the organisation.

\subsection{Improving Non-Compliance}

This study highlighted that rather than being a matter of deficient regulatory framework, the present predicament has more to do with a lack of regulatory enforcement. This has also been previously pointed out in the literature. In fact, the MFSA Representative held that before making any further changes to the existing code, the RA must initially review current practices to identify any "existing gaps" which will then be addressed accordingly, possibly through changing existing rules, or by means of developing new rules. Indeed, interviewees themselves pointed out to the need for more monitoring when asked what measures could be taken to improve the quality of the explanations. Despite the fact that Malta agreed with the setting up of a monitoring body to review the substance of the explanations provided (Ministry of Finance, the Economy and Investment, 2011), no such monitoring has yet taken place. It is clear that such monitoring is essential for the improvement of CG practices in Malta, not only for regulations to be enforced, but also because the 
pressure is thereby created on MLCs to improve in their reporting if the regulator shows more interest in $\mathrm{CG}$ practices.

\section{Conclusion}

We conclude that very few MLCs have embodied CG as a central part of their organisation and this is evident in the misapplication of the Code. In the first place, prior to the amendment of existing rules, enforcement of the existing regulatory framework is required. In this regard, regulatory involvement is essential, not only in the form of monitoring and enforcement but also in terms of providing further guidance to MLCs in the preparation of their CGS. As regards the auditor's role, while in some instances it is not clear what auditors are actually confirming in their report on $\mathrm{CG}$, widening the auditor's responsibilities may lead to independence issues.

Furthermore, this study confirms that the explanations for non-compliance with the $\mathrm{CG}$ Code as a whole are far from satisfactory. The vagueness of the Code itself and the lack of regulatory guidance may contribute to this inadequate disclosure. Nevertheless, entities seem to be aware of what is generally expected of them. Despite this, in some instances MLCs still fail to provide adequate explanations, confirming that they only comply cosmetically with the Code. Thus, there is much room for better explanations. At the same time, the lack of interest on the part of shareholders may prevent entities from realising that there is such a need.

Therefore, there is ample room for improvement in non-compliance with the CG Code. Regulatory enforcement of the existing rules is essential to identify possible ways in which the existing regulatory framework may be improved, together with increased efforts in educating both MLCs and shareholders on CG and its benefits.

\section{References:}

Akkermans, D., Van Ees, H., Hermes, N., Hooghiemstra, R., Van, D.L., Postma, T. \& Van Witteloostuijn, A. 2007. Corporate Governance in the Netherlands: an overview of the application of the Tabaksblat Code in 2004. Corporate Governance: An International Review, Vol. 15, No. 6, pp. 1106-1118.

Arcot, S., Bruno, V. \& Faure-Grimaud, A. 2010. Corporate governance in the UK: Is the comply or explain approach working? International Review of Law \& Economics, Vol. 30, No. 2, pp. 193-201.

Azzopardi, J.R. 2012. The board/management relationship aspect of corporate governance in Maltese listed companies. University of Malta: Faculty of Law.

Baldacchino, P.J., Baldacchino, J., Bezzina, F.H. \& Tipurić, D. 2015. Assessing the applicability of a corporate governance index in Maltese listed entities. International Journal of Transitions and Innovation Systems, 4, No. 1-2, pp. 43-64.

Baldacchino, P.J., Gatt, J., Tabone, N., Bezzina, F. 2018. The Nomination Committee in Maltese Listed Companies. In Tipurić, D., Labaš, D. (Ed.): 6th International OFEL Conference on Governance, Management and Entrepreneurship. New Business 
Models and Institutional Entrepreneurs: Leading Disruptive Change. April 13th 14th, Dubrovnik, Croatia, Governance Research and Development Centre (CIRU), Zagreb, pp. 125-139.

Baldacchino, P.J., Camilleri, C., Grima, S., Bezzina, F. 2017. Assessing incentive and monitoring schemes in the corporate governance of Maltese cooperatives. European Research Studies Journal, 20(3A), 179-197.

Bank of Valletta plc. 2016. Annual Report \& Financial Statements 2016. Available from https://www.bov.com/content/financial-reports.

Bezzina, F.H., Baldacchino, P.J. \& Azzopardi, J.R. 2014. The Corporate Governance Relationship between the Board and Management in Maltese Listed Companies. In Darko, T., Raguz, R.V. \& Podrug, N. (Eds.) Rethinking Corporate Governance, Pearson, pp. 1-15.

Bozec, R. \& Dia, M. 2012. Convergence of corporate governance practices in the postEnron period: Behavioural transformation or box-checking exercise? Corporate Governance, Vol. 12, No. 2, pp. 243-256.

Cauchi, M. 2009. Corporate governance reporting and its significance in Maltese listed companies. University of Malta, Faculty of Economics, Management and Accountancy, Department of Accountancy.

Davies, P., Ferrarini, G., Hopt, K., Pietrancosta, A., Skog, R., Soltysinski, S., Winter, J. \& Wymeersch, E. 2011. European Company Law Experts' Response to the European Commission's Green Paper. The EU Corporate Governance Framework. Available from https://ssrn.com/abstract $=1912548$.

Debono, C. 2016. Recent trends in corporate governance statements and its review. University of Malta, Faculty of Economics, Management and Accountancy, Department of Accountancy.

European Commission. 2011. Green Paper: The EU corporate governance framework, http://ec.europa.eu/internal_market/company/docs/modern/com2011-164_en.pdf.

European Commission. 2014. Commission Recommendation of 9 April 2014 on the quality of corporate governance reporting ("comply or explain"), http://eurlex.europa.eu/legal-content/EN/TXT/PDF/?uri=CELEX:32014H0208\&from=EN.

Financial Reporting Council. 2011. Response to the European Commission Green Paper on the EU Corporate Governance Framework, http://www.frc.org.uk/images/uploaded/documents/

FRC \%20response\%20to\%20the\%20Green\%20Paper\%20on\%20the\%20EU\%20co rporate $\% 20$ governance $\% 20$ framework $\% 20 \mathrm{July} \% 202011$.pdf.

Giannakopoulou, N.E., Stamatopoulos, V.T. and Thalassinos, I.E. 2016. Corporate governance in shipping: An overview. Maritime Policy and Management, Vol. 43(1), 19-38

Grima, S., Seychell, S., Bezzina, F. 2017. Investigating Factors Predicting Derivative Mishandling: A Sociological Perspective. European Research Studies Journal, 20(4A), 3-17.

Hooghiemstra, R. \& van Ees, H. 2011. Uniformity as a response to soft law: Evidence from compliance and non-compliance with the Dutch corporate governance code. Regulation \& Governance, Vol. 5, No. 4, pp. 480-498.

Horak, H. \& Bodiroga-Vukobrat, N. 2011. EU member states' experience with the 'comply or explain' principle in corporate governance. Croatian yearbook of European law and policy, Vol. 7, pp. 179-200.

International Hotel Investments plc. 2016. Annual Report and Financial Statements 2016. Available from http://www.ihiplc.com/investors/financial-reports. 
Keay, A. 2014. Comply or explain in corporate governance codes: in need of greater regulatory oversight? Legal Studies, Vol. 34, No. 2, pp. 279-304.

Listing Authority. 2018. Listing Rules. Available from http://www.mfsa.com.mt/pages/viewcontent.aspx?id=267.

Lombard Bank Malta plc. 2016. Annual Report 2016. Available from http://www.lombardmalta.com/en/financial-results.

MacNeil, I. \& Li, X. 2006. Comply or Explain: market discipline and non-compliance with the Combined Code. Corporate Governance: An International Review, Vol. 14, No. 5, pp. 486-496.

Malta Financial Services Authority (MFSA). 2011. The Code of Principles of Good Corporate Governance. Available from http://www.mfsa.com.mt/pages/viewcontent.aspx?id=365.

Malta Properties Company plc. 2016. Annual Report 2016. Available from http://maltaproperties.com.mt/annual-general-meeting.

Medserv plc. 2016. Annual Report and Financial Statements 2016. Available from http://www.medservenergy.com/medserv-plc-financial-statements.

MIDI plc. 2016. Annual Report and Consolidated Financial Statements 31 December 2016. Available From http://www.midimalta.com/en/annual-reports.

Ministry of Finance, the Economy and Investment. 2011. Malta's replies to the questions in Green Paper - The EU Corporate Governance Framework. Available from http://ec.europa.eu/internal_market/consultations/2011/corporate-governanceframework/public-authorities/government-of-malta_en.pdf.

Plaza Centres plc. 2016. Annual Report and Financial Statements 2016. Available from https://www.plaza-shopping.com/company-notifications-and-publications.

RS2 Software plc. 2016. Annual Report and Financial Statements 2016. Available from https://www.rs2.com/annual-report-and-financial-statements-2016.

Schembri, B. 2016. Performance evaluation of the board of directors in Maltese listed companies, University of Malta; Faculty of Economics, Management and Accountancy, Department of Accountancy.

Seidl, D., Sanderson, P. \& Roberts, J. 2009. Applying Comply-or-Explain: Conformance with Codes of Corporate Governance in the UK and Germany. Centre for Business Research: University of Cambridge, Working Paper, No. 389.

Seidl, D., Sanderson, P. \& Roberts, J. 2013. Applying the 'comply-or-explain' principle: discursive legitimacy tactics with regard to codes of corporate governance. Journal of Management \& Governance, Vol. 17, No. 3, pp. 791-826.

Sergakis, K. 2015. Deconstruction and Reconstruction of the "Comply or Explain" Principle in EU Capital Markets. Accounting, Economics and Law, 5(3), 233-288.

Shrives, P.J. \& Brennan, N.M. 2015. A typology for exploring the quality of explanations for non- compliance with UK corporate governance regulations. The British Accounting Review, Vol. 47, No. 1, pp. 85-99.

Suryanto, T., Grima, S. 2018. The Corporate Decision in Indonesia: A Result of Corporate Governance Requirements, Earnings Management and Audit Reports. Contemporary Issues in Finance: Governance and Regulations' Contemporary Issues (Contemporary Studies in Economic and Financial Analysis, Volume 99) Emerald Group Publishing Limited, Chapter 9, pp. 183- 206.

Tigne Mall plc. 2016. Annual Report and Financial Statements 31 December 2016. http://www.thepointmalta.com/investor-relations/companyannouncements/annual-reports-and-financial-statements. 


\section{Appendices:}

Table A1: Corporate Governance Statements Analysed

\begin{tabular}{|c|c|c|c|}
\hline Company Name & 2012 & 2014 & 2016 \\
\hline Bank of Valletta plc & $\checkmark$ & $\checkmark$ & $\checkmark$ \\
\hline HSBC Bank Malta plc & $\checkmark$ & $\checkmark$ & $\checkmark$ \\
\hline Lombard Bank Malta plc & $\checkmark$ & $\checkmark$ & $\checkmark$ \\
\hline Mapfre Middlesea plc & $\checkmark$ & $\checkmark$ & $\checkmark$ \\
\hline Simonds Farsons Cisk plc & $\checkmark$ & $\checkmark$ & $\checkmark$ \\
\hline GO plc & $\checkmark$ & $\checkmark$ & $\checkmark$ \\
\hline International Hotel Investments plc & $\checkmark$ & $\checkmark$ & $\checkmark$ \\
\hline Plaza Centres plc & $\checkmark$ & $\checkmark$ & $\checkmark$ \\
\hline GlobalCapital plc & $\checkmark$ & $\checkmark$ & $\checkmark$ \\
\hline FIMBank plc & $\checkmark$ & $\checkmark$ & $\checkmark$ \\
\hline Malta International Airport plc & $\checkmark$ & $\checkmark$ & $\checkmark$ \\
\hline Santumas Shareholdings plc ${ }^{a}$ & $x$ & $x$ & $\checkmark$ \\
\hline Medserv plc & $\checkmark$ & $\checkmark$ & $\checkmark$ \\
\hline Grand Harbour Marina plc & $\checkmark$ & $\checkmark$ & $\checkmark$ \\
\hline MaltaPost plc & $\checkmark$ & $\checkmark$ & $\checkmark$ \\
\hline RS2 Software plc & $\checkmark$ & $\checkmark$ & $\checkmark$ \\
\hline MIDI plc & $\checkmark$ & $\checkmark$ & $\checkmark$ \\
\hline Malita Investments plc & $\checkmark$ & $\checkmark$ & $\checkmark$ \\
\hline Tigne Mall plc & $x$ & $\checkmark$ & $\checkmark$ \\
\hline Pefaco International plc & $x$ & $\checkmark$ & $x$ \\
\hline Malta Properties Company plc ${ }^{d}$ & $x$ & $x$ & $\checkmark$ \\
\hline PG plc & $x$ & $x$ & $x$ \\
\hline Trident Estates plc ${ }^{f}$ & $x$ & $x$ & $x$ \\
\hline Total for each year & 17 & 19 & 20 \\
\hline Total reports analysed & \multicolumn{3}{|c|}{56} \\
\hline
\end{tabular}

\section{Notes:}

${ }^{a}$ Santumas Shareholdings plc held a Collective Investment Scheme License up until 9 October 2014. On the same date it was admitted as a Property Company on the Malta Stock Exchange.

${ }^{b}$ Tigne Mall plc was admitted to listing in May 2013.

cPefaco International plc was admitted to listing on the Malta Stock Exchange on $25^{\text {th }}$ July 2014. The annual report for the year ending $31^{\text {st }}$ December 2016 was not available on the company website, or on the MFSA website.

${ }^{d}$ Malta Properties Company plc was listed in 2015.

${ }^{e} P G$ plc was listed on $25^{\text {th }}$ November 2016.

${ }^{f}$ Trident Estates plc was admitted on 30 ${ }^{\text {th }}$ January 2018.

\section{Interview Schedule}

This appendix consists of the interview schedule used to collect the data for the purpose of this dissertation. The number of responses for each of the closed-ended questions - Qn5, Qn8, Qn22 and Qn30 - are also included in bold and italics in the schedule. 
Section A

The Maltese Regulatory Framework

Part 1 - The Code of Principles of Good Corporate Governance

1. Do you believe that the Code allows for the setup of appropriate corporate governance structures in listed companies? In what ways?

2. Should the Code of Principles of Good Corporate Governance be made mandatory? Why/Why not?

3. Should the Code distinguish between small, medium and large listed companies? Why/why not?

Part 2 - The Comply-or-Explain Principle

1. The Code is based on the 'Comply-or-Explain' approach, whereby companies are expected to either comply with the principles of the Code or otherwise provide reasons for non-compliance. To what extent do you believe that this is an effective approach to corporate governance?

2. Do you agree that the comply-or-explain principle:

\begin{tabular}{|ll|l|l|l|l|l|}
\hline Please rate: & $\begin{array}{l}\text { Strongly } \\
\text { Disagree }\end{array}$ & Disagree & Neutral & Agree & $\begin{array}{l}\text { Strongly } \\
\text { Agree }\end{array}$ \\
\hline 2.1. & Grants Flexibility. & & & & & \\
\hline $2.2 . \quad \begin{array}{l}\text { Acknowledges that a } \\
\text { 'one-size-fits-all' } \\
\text { approach to corporate } \\
\text { governance is } \\
\text { inappropriate. }\end{array}$ & & & & & \\
\hline 2.3. & $\begin{array}{l}\text { Allows shareholders to } \\
\text { appropriately monitor } \\
\text { and assess corporate } \\
\text { governance practices in } \\
\text { different organisations. }\end{array}$ & & & & & \\
\hline 2.4. & $\begin{array}{l}\text { Requires adequate and } \\
\text { meaningful } \\
\text { explanations for non- } \\
\text { compliance to fulfil its } \\
\text { purpose. }\end{array}$ & & & & & \\
\hline 2.5. & $\begin{array}{l}\text { Is undermined by } \\
\text { shareholders' lack of } \\
\text { interest in monitoring it } \\
\text { in practice. }\end{array}$ & & & & & \\
\hline
\end{tabular}

Section B

The Roles of Auditors and the Regulatory Authority

4. Do you believe that shareholders adequately monitor and respond to noncompliance? If yes, from your experience, in what ways do shareholders do so?

Part 1 - Auditors

5. For interviewees in audit firms. To what extent do you believe that your role in corporate governance is relevant?

6. Do you agree with these statements?

\begin{tabular}{|l|l|l|l|l|l|}
\hline Please rate: & $\begin{array}{l}\text { Strongly } \\
\text { Disagree }\end{array}$ & Disagree & Neutral & Agree & $\begin{array}{l}\text { Strongly } \\
\text { Agree }\end{array}$ \\
\hline
\end{tabular}




\begin{tabular}{|c|c|c|c|c|c|c|}
\hline 6.1. & $\begin{array}{l}\text { The auditor's report on } \\
\text { corporate governance } \\
\text { increases shareholders' } \\
\text { confidence of the } \\
\text { Corporate Governance } \\
\text { Statement. }\end{array}$ & & & & & \\
\hline $\begin{array}{l}6.2 . \\
\text { (i) }\end{array}$ & $\begin{array}{l}\text { In practice, auditors } \\
\text { do not really provide } \\
\text { assurance on the } \\
\text { adequateness of the } \\
\text { corporate governance } \\
\text { function, and; }\end{array}$ & & & & & \\
\hline (ii) & $\begin{array}{l}\text { The law is unclear in } \\
\text { this regard. }\end{array}$ & & & & & \\
\hline $\begin{array}{l}6.3 . \\
\text { (i) }\end{array}$ & $\begin{array}{l}\text { Auditors should } \\
\text { provide an opinion on } \\
\text { whether explanations } \\
\text { for non-compliance } \\
\text { are adequate, and; }\end{array}$ & & & & & \\
\hline (ii) & $\begin{array}{l}\text { The law should } \\
\text { require this }\end{array}$ & & & & & \\
\hline 6.4 . & $\begin{array}{l}\text { Shareholders would } \\
\text { find the auditor's report } \\
\text { on corporate } \\
\text { governance more } \\
\text { relevant if the auditor } \\
\text { expressed an opinion on } \\
\text { non-compliance with } \\
\text { the Code. }\end{array}$ & & & & & \\
\hline 6.5 & $\begin{array}{l}\text { The auditor's current } \\
\text { role in corporate } \\
\text { governance is } \\
\text { sufficient. }\end{array}$ & 0 & 3 & 0 & 10 & 0 \\
\hline
\end{tabular}

7. Are there any other/alternative ways in which the auditor may be involved in an entity's corporate governance function?

Part 2 - The Regulatory Authority

Questions 10 - 16 apply only for interviewees in the regulatory authority.

8. Is it within the capacity of the authority to initiate action against a listed company for non-compliance?

9. If yes, has the authority ever instituted action against a company? What type?

10. To your knowledge, has the authority ever received complaints regarding noncompliance and the explanations thereof from shareholders and/or other stakeholders?

11. Do you think that more involvement on your part could improve the issue of the lack of adequate explanations for non-compliance?

12. If yes, what type of involvement?

13. What sanctions, if any, may be imposed?

14. Have such sanctions ever been imposed? If not, should they be introduced? 
Questions 17 - 20 apply only for interviewees in listed companies and audit firms.

15. Should there be more involvement in corporate governance practices by the regulatory authority? Why/Why not?

16. If yes, what type of involvement?

17. Should sanctions be imposed by the regulator in serious cases of non-compliance?

18. If, yes what type of sanctions? 